\title{
A study on mast cell variation in neoplastic and non neoplastic disease of uterine cervix
}

\author{
Mainali $\mathrm{N}^{1}$, Sinha $\mathrm{AK}^{1}$, Upadhaya $\mathrm{P}^{1}$, Uprety $\mathrm{D}^{2}$ \\ ${ }^{I}$ Department of Pathology, B.P. Koirala Institute of Health Sciences, Dharan, Nepal \\ ${ }^{2}$ Department of Obstetrics and Gynecology, B.P. Koirala Institute of Health Sciences, Dharan, Nepal
}

\section{Keywords: \\ Cervicitis; \\ Carcinoma}

\begin{abstract}
Background: Mast cells are heterogeneous group of immune cells involved in multiple biological events. The significance of mast cells in uterine tumor surveillance has been studied with conflicting results. The presence of mast cell in tumor has been described as evidence of a host immunologic anti tumor response and if they are abundant the prognosis is good. However in other studies, with the help of different granules of mast cell, it is said to be very closely related with angiogenesis and tumor invasion. The study aims to analyze the histomorphologic changes with special reference to mast cells in different neoplastic and non neoplastic disease of uterine cervix, and also the relationship of the mast cell population with degree of anaplasia and mitotic figures.
\end{abstract}

Materials and methods: Cervical biopsies received in the department of Pathology for HPE were stained with H\& E stain and toludine blue for the identification of mast cell

Result: Out of a total of 100 cases, 82 were non neoplastic cases with the mean mast cell count of 83.73 and mean age of patient being 44.30 year. Eighteen neoplastic cases were included which had mean mast cell count of 13.5 and mean age of 49.5 year.

Conclusion: Mast cell was found to be highest in non Neoplastic lesion with increase count in polypoidal cervicitis. There was a statistical significance variation between mast cell count in neoplastic and non Neoplastic disease of the cervix. However,role of age in mast cell count was least significant.

\section{INTRODUCTION}

Mast cells are heterogeneous group of immune cells involved in multiple biological events. The multiple biologic functions of mast cell appear to be mediated by the variety of active molecules. ${ }^{1}$ Mast cell was identified and named

\section{Correspondence:}

Dr. Nirajan Mainali, $M D$

Lecturer, Department of Pathology

Nobel Medical college teaching hospital \& research center,

Biratnagar, Nepal

Email:mainali_nirajan@hotmail.com by Paul Erlich in $1878 .^{2}$ In normal conditions, there are no circulating mast cells, since the progenitor cells migrate to peripheral tissues as immature cells, differentiating in situ. ${ }^{3}$ Mast cell are found in almost all of the major organs and tissues of the body. ${ }^{4}$

The significance of mast cells in uterine tumor surveillance has been studied with conflicting results. The presence of mast cell in tumor has been described as evidence of a host immunologic anti tumor response and if they are abundant 
Table 1: Mast cells in non neoplastic lesion of cervix

\begin{tabular}{|c|c|c|c|c|c|}
\hline Non neoplastic lesion & No. of cases & MEAN Age(yr) & $\begin{array}{c}\text { Mast cell count } \\
(\text { mean })\end{array}$ & Range/ 10hpf & $\begin{array}{l}\text { Standard } \\
\text { deviation }\end{array}$ \\
\hline Polypoidal cervicitis & 7 & 37.28 & 114.00 & $40-250$ & 71.52 \\
\hline Chronic cervicitis & 42 & 45.67 & 81.90 & $29-144$ & 31.13 \\
\hline Chr. Cervicitis with epidermadization & 11 & 50.73 & 75.82 & $46-120$ & 22.75 \\
\hline Chr. Cervicitis with squamous metaplasia & 12 & 40.83 & 76.92 & $25-125$ & 30.66 \\
\hline Chronic Cervicitis with ulceration & 1 & 45 & 146 & - & - \\
\hline Normal cervix & 9 & 40.11 & 80.56 & $50-110$ & 19.95 \\
\hline
\end{tabular}

the prognosis is good. ${ }^{2}$ However in other studies, with the help of different granules of mast cell, it is said to be very closely related with angiogenesis and tumor invasion. One of such study was done by Bribiesca et al in 2001. ${ }^{5}$

In this study, we have tried to demonstrate and compare the presence of mast cell in neoplastic and non neoplastic condition as well as their value as prognostic indicator along with the relationship of mitotic count with mast cell number.

The study aims to analyze the histomorphologic changes with special reference to mast cells in different neoplastic and non neoplastic disease of uterine cervix, and also the relationship of the mast cell population with degree of anaplasia and mitotic figures.

\section{MATERIAL AND METHODS}

The material used for the study was obtained from cervical biopsies and hysterectomy specimens received in the Department of Pathology over a period of one year (January 2010 - December 2010). The tissue was routinely stained with hematoxylin and eosin stain. In order to identify the mast cells with the typical metachromatic granules, $1 \%$ toluidine blue stain was used.

\section{RESULTS}

Total of 100 cases were included in this study which comprises of 29 cervical biopsies specimen and 71 hysterectomy specimen. The present study comprised of 82 non neoplastic and 18 neoplastic lesion of cervix (histopathological diagnosis).

Non neoplastic lesion comprised of 16 biopsies and 66 hysterectomy specimen. The range and mean of mast cells in non neoplastic lesion of cervix are shown in table 1.

Neoplastic cervical lesions were 18 cases with 13 biopsies and 5 hysterectomies. The range, mean of mast cells and mitosis count in neoplastic lesion of cervix are shown in table 2 (fig 1-3).
Table 2: Mast cells and mitosis in Neoplastic lesion of cervix

\begin{tabular}{|c|c|c|c|}
\hline NEOPLASTIC LESION & & $\begin{array}{c}\text { MAST CELL } \\
\text { NUMBER }\end{array}$ & $\begin{array}{c}\text { MITOTSIS } \\
\text { COUNT }\end{array}$ \\
\hline \multirow{5}{*}{ Metastatic carcinoma } & Mean & 18.50 & 11.50 \\
\hline & Number & 2 & 2 \\
\hline & Std.Deviation & 10.61 & 2.12 \\
\hline & Minimum & 11 & 10 \\
\hline & Maximum & 26 & 13 \\
\hline \multirow{5}{*}{$\begin{array}{l}\text { Large cell non kera- } \\
\text { tinizing } \\
\text { Squamous cell } \\
\text { Carcinoma }\end{array}$} & Mean & 15.43 & 39.00 \\
\hline & Number & 7 & 7 \\
\hline & Std.Deviation & 10.49 & 14.20 \\
\hline & Minimum & 4 & 24 \\
\hline & Maximum & 30 & 61 \\
\hline \multirow{5}{*}{$\begin{array}{l}\text { Large cell } \\
\text { Keratinizing } \\
\text { Squamous cell } \\
\text { carcinoma }\end{array}$} & Mean & 12.67 & 46.67 \\
\hline & Number & 3 & 3 \\
\hline & Std.Deviation & 14.15 & 24.95 \\
\hline & Minimum & 4 & 28 \\
\hline & Maximum & 29 & 75 \\
\hline \multirow{5}{*}{ Carcinoma in situ } & Mean & 6.75 & 38.25 \\
\hline & Number & $\begin{array}{l}4 \\
189\end{array}$ & 4 \\
\hline & Std.Deviation & 1.89 & 17.29 \\
\hline & Minimum & $\begin{array}{l}4 \\
8\end{array}$ & 14 \\
\hline & Maximum & & 55 \\
\hline \multirow{5}{*}{ Others } & Mean & 16.50 & 31.50 \\
\hline & Number & 2 & 2 \\
\hline & Std.Deviation & 16.26 & 2.12 \\
\hline & Minimum & 5 & 30 \\
\hline & Maximum & 28 & 33 \\
\hline \multirow{5}{*}{ Total } & Mean & 13.50 & 36.22 \\
\hline & Number & 18 & 18 \\
\hline & Std.Deviation & 10.08 & 17.19 \\
\hline & Minimum & 4 & 10 \\
\hline & Maximum & 30 & 75 \\
\hline
\end{tabular}

\section{Mast cell variation in non neoplastic and neoplastic lesion:}

A total of 82 non neoplastic (fig. 4) cases were included in the study with the mean mast cell count of 83.73 and mean age of patient being 44.30 year. Eighteen neoplastic cases were included which had mean mast cell count of 13.5 and mean age of 49.5 year. Variations are listed in the table 3 .

A significant variation was noted when mast cell among the non neoplastic and neoplastic cases were compared with a $\mathrm{p}$ value of .000 . No statistical significance was noted in age between the non neoplastic and neoplastic lesion. No 


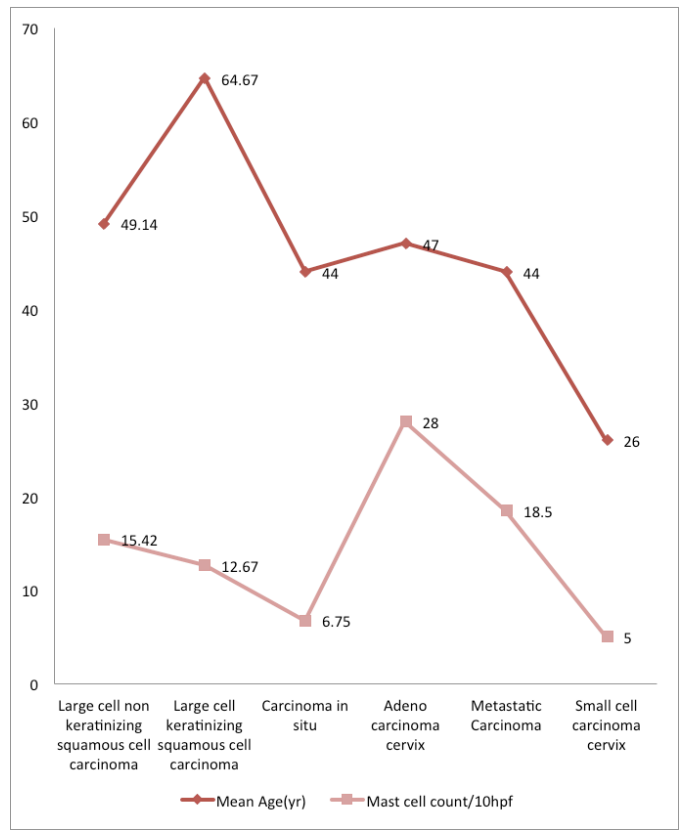

Line diagram showing comparison of mast cell count and age of the patient among the different neoplastic lesion of cervix.

statistical significance was noted within the non neoplastic group in mast cell count with a p value of 0.0787 (table 4) (fig. 4,5).

\section{Mast cell and mitotic count figures:}

No statistical significance were noted between the mitotic count and mast cell count in the neoplastic lesion( $p$ value of 0.456 ) but mast cell were consistently decreasing when mitotic figures were increasing. In some group it was noted to increase. The relation may be due to the less number of neoplastic cases. (Table 5).

\section{DISCUSSION}

It is important to recognize the range of non neoplastic and neoplastic lesion of cervix and to differentiate different neoplastic lesion. Cervical biopsies can be difficult to interpret sometimes on which the associated features including mast cell variation can be beneficial to interpret. Comparison of mast cell with mitotic figures can be of beneficial value when significant relation can be established in small biopsies.

In this study we have tried to establish the relationship of mast cell between non neoplastic and neoplastic lesion of cervix along with the mitotic figures with mast cell population.

Various studies have been done in the past for mast cell counts. In our study we have taken a single section of specimen for H\&E and toludine blue stain. H\&E stained slide was used for the microscopic diagnosis of the cervix and mast cell was then counted in toludine blue stained slide in ten high power fields $(\mathrm{x} 400)$. Some authors have counted mast cell in similar way 6 , where as other have counted a single high power field in each case and mast cell was graded as one plus for mast cell less than 5 per hpf, two plus for mast cell count of five to ten per hpf and three plus for mast cell count of more than ten per hpf. ${ }^{7}$

In our study, 71 cases were that of hysterectomy and 29 were that of cervical biopsies. Majority of other studies were done only in cervical biopsies ${ }^{2,7}$ while few others have done study cervical biopsies as the predominant specimen. ${ }^{6}$

In our study, Most encountered case among the non neoplastic lesion was that of chronic cervicitis (42 cases). In the study done by R. naik et al6 normal cervix was the highest number of non neoplastic lesion. In our study large cell non keratinizing squamous cell carcinoma was the most common neoplastic lesion (32 cases) as similar to the study done by R.Naik et al. ${ }^{6}$

Mast cell in non neoplastic lesion was highest among the polypoidal cervicitis with the mean mast cell count of 117.71 similar to the study done by R. Naik et al. ${ }^{6}$

Among the neoplastic lesion mast cell was highest in adenocarcinoma of cervix with the count of 28 but the number of case was only one. In other studies, carcinoma in situ was the highest among neoplastic lesion. ${ }^{6,8}$ In the study done by R. naik et al, adenocarcinoma had a mean mast cell count of 58.93. Carcinoma in situ had a higher number of mast cell count of 100 but the number of case of carcinoma in situ was just one. ${ }^{6}$

Table 3: Mast cell variation in non neoplastic and neoplastic lesion

\begin{tabular}{llcccccccc}
\hline & \multicolumn{1}{c}{ Lesion } & $\begin{array}{c}\text { NUMBER } \\
\text { OF CASES }\end{array}$ & RANGE & MEAN & $\begin{array}{c}\text { STANDARD } \\
\text { DEVIATION }\end{array}$ & $\begin{array}{c}\text { STANDARD } \\
\text { ERROR } \\
\text { MEAN }\end{array}$ & P VALUE & REMARKS \\
\hline $\begin{array}{l}\text { AGE } \\
\text { (YEAR) }\end{array}$ & NON NEOPLASTIC & 82 & $21-71$ & 44.30 & 11.20 & 1.24 & .082 & Not significant \\
& NEOPLASTIC & 18 & $26-70$ & 49.50 & 12.11 & 2.86 & .108 & Not significant \\
MAST CELL & NON NEOPLASTIC & 82 & $25-250$ & 83.73 & 35.29 & 3.90 & .000 & Significant \\
COUNT/10HPF & NEOPLASTIC & 18 & $4-30$ & 13.50 & 10.08 & 2.38 & .000 & Significant
\end{tabular}


Table 4: Non neoplastic group and mast cells

\begin{tabular}{|c|c|c|c|c|c|c|}
\hline Types & Number of cases & Range/10hpf & Mean & Std. Deviation & P value & Remarks \\
\hline Chronic cervicitis with ulceration & 1 & - & 146.00 & - & \multirow{7}{*}{0.0787} & \multirow{7}{*}{ Not significan } \\
\hline Chronic Cervicitis & 42 & $29-144$ & 81.90 & 31.13 & & \\
\hline Chronic Cervicitis with epidermadization & 11 & $46-120$ & 75.82 & 22.75 & & \\
\hline Chronic Cervicitis with Squamous metaplasia & 12 & $25-125$ & 76.92 & 30.66 & & \\
\hline Polypoidal Cervicitis & 7 & $40-250$ & 114.00 & 71.52 & & \\
\hline Normal Cervix & 9 & $50-110$ & 80.56 & 19.95 & & \\
\hline Total & 82 & $25-250$ & 83.73 & 35.29 & & \\
\hline
\end{tabular}

Table 5: Mast cell and mitotic count figures in Neoplastic cases

\begin{tabular}{lcc}
\multicolumn{1}{c}{ NEOPLASTIC LESION } & MEAN MAST CELL NUMBER & MEAN MITOTSIS COUNT \\
\hline Metastatic carcinoma & 18.50 & 11.50 \\
Large cell non keratinizing & 15.43 & 39.00 \\
Squamous cell Carcinoma & 12.67 & 6.75 \\
Large cell Keratinizing Squamous cell Carcinoma & 16.50 & 38.25 \\
Carcinoma in situ & $\mathbf{1 3 . 5 0}$ \\
Others & 31.50 \\
\hline Total & $\mathbf{3 6 . 2 2}$ \\
\hline
\end{tabular}

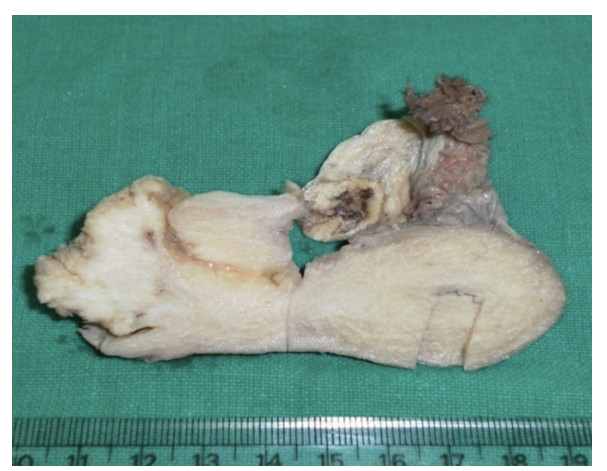

Figure 1: Gross photograph of Cervical Carcinoma.

In our study, there was a well established relationship between the mast cell variation in between non neoplastic and neoplastic lesion of cervix with the count being high in non neoplastic lesion. In other studies similar relation between non neoplastic and neoplastic lesion were found. ${ }^{6,7}$

Mast cell was mainly present near the area of inflammation, beneath surface epithelium, around dilated glands and vessels in our study. In other studies, mast cells were around the blood vessels, cervical glands and area of inflammation but not beneath the surface epithelium. ${ }^{6,7}$ In the study conducted by Nozaka et $\mathrm{al}^{9}$ mast cells were present beneath the surface epithelium.

The association of mast cells with mitotic figures

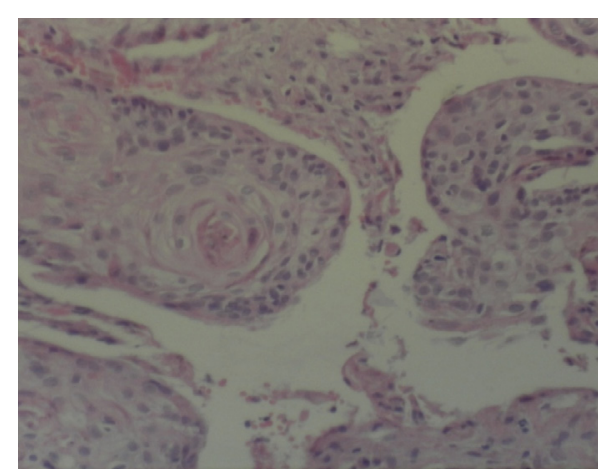

Figure 2: Large cell Keratinizing Squamous Cell Carcinoma. ( $H \& E x 400)$ consistently decreased with increased dedifferentiation in a study done by P.C Jain et al. ${ }^{7}$ In our study there was no statistical significance between the mitotic figures and the mast cell count but mast cell was increasing with increase in count of mitotic figures. The variation of it with other study may be due to involvement of less sub epithelium in the biopsies and less number of cases with malignancy. There was an inverse relationship between the mitotic figure count and mast cell in a study conducted by R. Naik et al. ${ }^{6}$ However, in a study conducted by R.M.Graham et al, 2 there was positive correlation between the mast cell count and the mitotic figure when counted in the same oil immersion field.

In our study, the age range was between 24-71 years, with the mean of 45.24 years. While in one of the study patient 


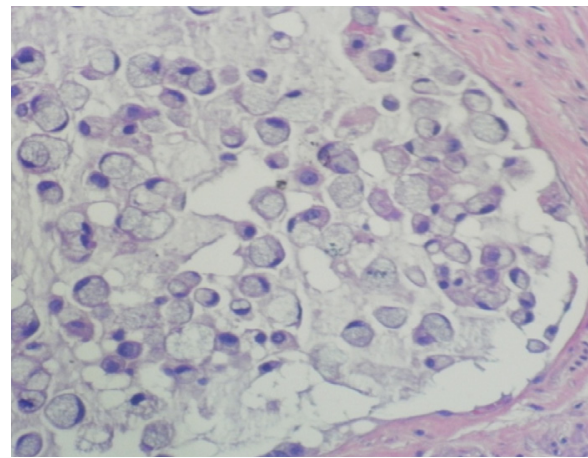

Figure 3: Metastatic Signet Cell Carcinoma (H\&E, X400).

age range was $22-75$ years. $^{7}$

There was no correlation between mast cell count and the age of the patient in our study which was similar to other studies. ${ }^{2,7}$

\section{CONCLUSION}

Mast cell was higher in polypoidal cervicitis then in any other non neoplastic lesion. Large cell non Keratinizing squamous cell carcinoma was the most common neoplastic lesion encountered in the department of pathology, BPKIHS. Mast cell was higher among the metastatic lesion of cervix among the neoplastic lesion. There is a statistical significant correlation between the mast cell count of non neoplastic and neoplastic lesion of cervix with least number of mast cell present in the neoplastic lesion. There is no relation between the age of the patient and the mast cell count. There is no relation between the age of the patient and the nature of cervical disease (non neoplastic or neoplastic). Mitotic figures and the mast cell count doesn't have statistical significant relation.

\section{REFERENCES}

1. Cabanillas SA, Sahalper JA, Nicovani SM, Rudolph MI. Characterization of mast cells according to their content of tryptase and chymase in normal and neoplastic human uterine cervix. Int J Gynaecol Obstet 2002;12:92-8. Crossref

2. Graham RM, Graham JB. Mast cells and cancer of cervix. Surg Gynec Obstet 1966;123;3-9.

3. Graterol IJ, Finol HJ, Correnti C, Avila M. Untrastructural changes in premalignant and malignant lesions of the uterine cervix with papilloma virus infection. Journal of cancer research and experimental Oncology 2010; 2;35-42.

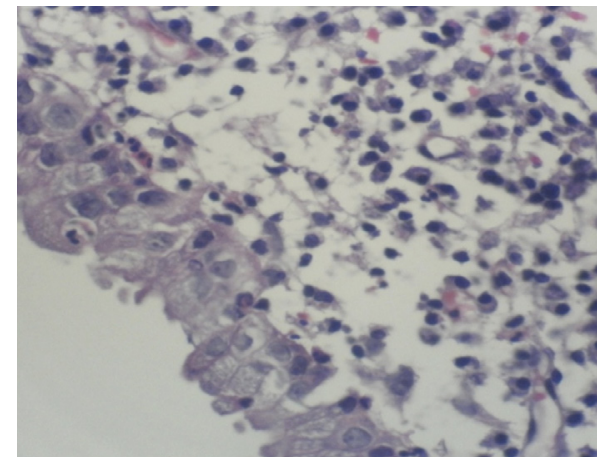

Figure 4: Chronic Cervicitis, Cervix (H\&E, X400).

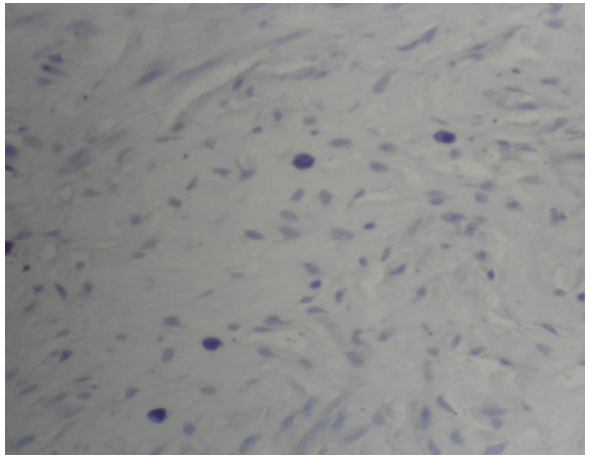

Figure 5: Mast Cell in the stroma in the Non neoplastic lesion of Cervix (Toludine Blue, X200).

4. Crivellato E, Ribatti D. Involvement of mast cells in angiogenesis an chronic inflammation. Current drug targets-inflammation \& allergy 2005;4:9-11. Crossref

5. Bribiesca BL, Wong A, Utrera D, Castellanos E. The role of mast cell tryptase in neoangiogenesis of premalignant and malignant lesions of the uterine cervix. J Histochem cytochem 2001;49:1061-26. Naik R, Pai RM, Dinghe P. Mast cell profile in uterine cervix. Indian j pathol micro 2004; 47;178-80.

7. Jain PC, Singh SN, Pratap VK, Lahiri B. Connective tissue changes and mast cell variations in benign and malignant lesions of the uterine cervix. Int surg 1977;62:358-60.

8. Jing Y, Xue RM, Zhang ZY, Yao HW, Dong ZL. Distribution and histochemical characteristics of mast cells in stroma of the cervix squamous cell carcinoma. Chin Med J 1993;106:698-702.

9. Nozaka K, Simpson WL. Mast cell in the human pylorus and cervix. Anat Rec.1962;142:163. 